\title{
Students' Decision-Making in Education for Sustainability-Related Extracurricular Activities-A Systematic Review of Empirical Studies
}

\author{
Carola Garrecht *, Till Bruckermann 1 and Ute Harms \\ Department of Biology Education, Leibniz Institute for Science and Mathematics Education (IPN) at \\ Kiel University, Olshausenstrasse 62, 24118 Kiel, Germany; bruckermann@ipn.uni-kiel.de (T.B.); \\ harms@ipn.uni-kiel.de (U.H.) \\ * Correspondence: garrecht@ipn.uni-kiel.de; Tel.: +49-431-880-3127
}

Received: 9 October 2018; Accepted: 22 October 2018; Published: 25 October 2018

\begin{abstract}
Equipping students with the capability to perform considerate decision-making is a key competence to elaborate socio-scientific issues. Particularly in the socio-scientific context of sustainable development, decision-making is required for the processing of information and the implementation of sustainable action. Extracurricular activities in education for sustainable development (ESD) offer a suitable format to promote decision-making due to their multidisciplinary and more informal structure. The purpose of this literature review is therefore to analyze empirical studies that explore students' (1) decision-making in (2) ESD-related (3) extracurricular activities. Following the preferred-reporting of items for systematic reviews and meta-analyses (PRISMA) guidelines, a systematic search yielded 19 out of 365 articles, each of them addressing all three components. Despite the theoretical relationship, hardly any empirical enquiry is found examining the trinomial interrelation with an equal consideration of all components. Contrarily, we argue that each is positioned in favor for only one component with the others serving as a backdrop. It follows that the full potential of an equal distribution between all three foci has not been explored yet; even though integrating sustainability-related issues in extracurricular activities displays a promising learning opportunity to optimally foster students' decision-making. Instead, studies that concentrate primarily on decision-making as a quantitatively measurable competence were predominant.
\end{abstract}

Keywords: decision-making; education for sustainable development; extracurricular activities

\section{Introduction}

Decision-making is one of the central cognitive processes of human beings [1] constituting a key component in formal teaching and learning [2,3]. On a daily base, plenty of our decisions are made intuitively. Making these decisions is often unconscious, quick and justified in a post-hoc process [4]. Besides this subliminal decision-making, some decision situations require more conscious considerations. According to Kahneman [5], these are drawn from a second and deliberate system of decision-making processes where coming to a decision is rather informed and therefore cognitively demanding. Decision-making hereby describes a rational process which causes the selection of a favored option or course of action among multiple alternatives that are based on specific criteria [6]. The actual acting upon a decision has been outlined a as complex and manifold process (e.g., [7-9]). However, the substantial role that the initial decision is playing for the following behavior was outlined in a meta-analysis by Webb \& Sheeran [10]. We therefore consider decision-making as a cognitive precursor to action and therefore do not examine the actual acting upon decisions within this paper. 
In the following, we argue that decision-making is required for students' processing of socio-scientific issues especially when these issues are connected to the field of sustainable development. We further unfold the argument that extended education offerings display a fruitful frame for the implementation and promotion of both, sustainability-related issues and decision-making.

Decision-making receives much attention in educational theory, practice and research. In the context of formal education, positive outcomes of shared decision-making are indicated for students on a class and school level [11], as well as an individual level [12]. Siribunnam, Nuangchalerm and Jansawang [12] showed that decision-making in the science classroom is prominently discussed on an individual student level. As such, decision-making in science education is described as students' ability to discuss issues from multiple viewpoints, whilst considering scientific data as well as underlying personal and societal values of each option, and to conclude informed decisions [13]. In the science classroom, decision-making is predominantly required to elaborate socio-scientific issues [14]. The term socio-scientific issue (SSI) refers to controversial themes that touch equally upon social matters and scientific content. Characteristically, these issues have no definite solution and contrarily offer multiple conceivable solution approaches [15-18]. Each SSI can thus be "informed by scientific principles, theories and data but cannot be fully determined by scientific considerations" [16] (p. 4), because it likewise demands dealing with ethical implications [15]. Driven by this intersection of social and scientific elements, SSIs do not only matter to the scientific community but are equally of interest for the society in general. The hereby emphasized real-world reference offers the potential to make science content more relevant for students [19-22] and to prepare students for their acting as responsible citizens $[23,24]$. SSIs in the context of sustainable development (SD) have been widely recorded in their exploration and enhancement of students' decision-making [16,25-27]. This predominance seems reasonable, since fostering students' capability to act and make decisions in the context of sustainable development appears to be a strongly favored competence according to student teachers [28]. In the context of SD, decision-making is needed to seize and solve issues such as the loss of biodiversity [29,30], climate change [31], ocean acidification [32,33], air pollution [34,35] and a rising use in chemicals [36]. These are only a few examples of multidisciplinary and manifold processes linked to globalization and technological growth posing complex and pressuring decision situations for today's and future generations [37]. Since sustainability, the framework to implement a sustainable development, is based on four pillars: environmental, social, economic and cultural sustainability [38-41], its nature can be described as multifaceted. In order to unravel this complexity for students, the provision of an appropriate and supporting approach in education, namely education for sustainable development (ESD), has been widely recognized [42]. The importance of an educational approach within this context has been underpinned by its explicit listing as an independent goal of the Sustainable Development Goals, seventeen goals that aim to advance a sustainable, joint and just life on earth [43]. The implementation of ESD has been shown to either directly or indirectly affect individuals' sustainability understanding [44], sustainability consciousness [45], and SD-related attitudes [46]. Within this ESD-context, decision-making can be described as the preceded transcription of the SD-concept into informed decisions which can lead, in a further step, to selected real-world actions [47]. Conclusively, decision-making is understood as a necessary competence in ESD for the processing and promotion of sustainable action. Teaching and learning through ESD is further characterized by (1) its level-crossing (i.e., pre-school to adult education), (2) instructional diverse compositions (formal, non-formal and informal) [37], and it is (3) understood as an approach rooting in various disciplines from humanities, natural sciences and social sciences [48]. Even though the school environment can constitute an educational platform to develop and apply ESD-actions in order to "promote the learning of skills, perspectives and values necessary to foster sustainable societies" [49] (p. 226), we will put forward two arguments in favor for an embedding in extracurricular activities. Firstly, regular school hours are formally tied to their discipline-driven curriculum. These disciplinary barriers might be too narrow in order to examine a highly complex and transdisciplinary learning content such as SD [50]. Contrarily, "sustainable development teaching will be richest when pupils experience 
these elements [...] in an integrated, non-fragmented way" [51] (p. 627). Secondly, regular school hours are commonly bound to formal requirements such as a rigorous temporal limitation, formal assessment and a tight interdependence with standards in national curricula [52,53]. Extracurricular activities, on the contrary, might pose a participatory, interdisciplinary and real-world-related learning context for the successful implementation of those ESD-actions $[54,55]$. In other words, detached from the clearly structured and assessment-focused schooling environment, extracurricular education allows to overcome structural boundaries and to implement an advantageous learning format for ESD [56]. With regards to ESD, the positive effect of extracurricular activities on students' knowledge and attitudes regarding sustainability and SD has been recorded in several studies [57-59]. Extracurricular activities are likewise perceived by teachers as valuable approach to foster competencies for citizenship, such as decision-making [60]. In this understanding an activating component is ascribed to young people and they are thus perceived as able to act as "critical-democratic citizens" [61] (p. 107). Commonly, extracurricular offerings are described as elective, additional and ungraded educational undertakings which are set inside the school facilities, but outside the regular school hours [62]. However, despite their supplementary and optional character many activities still fall within the scope of the curriculum and are closely linked to academic performance [62]. Aside from the academically-focused activities, their potential to "offer a means to express and explore one's identity, generate social and human capital, and offer a challenging setting outside of academics" [63] (p. 161) should be likewise discussed. The herby highlighted aspect of an extended area of influence is revisited in a much younger term acknowledged as extended education. Extended education can be understood as a particular form of extracurricular education, a form which is "usually subject to a low level of curricular requirement" [64] (p. 8) and therefore suitable for multidisciplinary topics such as SD. For this paper's research endeavor three main aspects are extracted from its definition: extended education includes the facilitation of (i) educationally structured and (ii) student-centered learning processes that are (iii) not part of the regular curriculum [65]. In order to further delimit what is understood as extended education within this paper, we will exclusively consider offerings that can be set in the wider school context [62].

\section{Research Question and Aims}

On a generic level, decision-making has been outlined as a key competence for a participatory living in the 21st century. In the narrower context of formal education, this theoretical derivation highlighted decision-making as a central objective in science education playing a vital role in students' processing of SSIs. Particularly SSIs that are set within the multifaceted nature of SD promote the development of decision-making and likewise foster students' involvement, knowledge and attitudes regarding SD. As such, decision-making has been shown as valuable competence in the context of ESD. Within this ESD context, extended education activities have been represented as suitable stage offering a multidisciplinary and more informal learning context. In light of these theoretical underpinnings, we follow the argument that ESD-related extended education activities hence offer both, multifaceted problems and lower boundaries than formal education and are therefore a promising learning opportunity to promote decision-making. The exploration of this threefold overlap will thus be the main focus of the here presented systematic literature review (see Figure 1).

Within this review we aim to explore the intersection displayed in ESD-related extended education offerings addressing students' decision-making. As such, the paper predominantly lines up with topical studies examining the importance of students' decision-making in broader educational contexts (e.g., [66]) as well as its role in particularly sustainability-related education contexts (e.g., [67]). Yet, in more general terms, it also contributes to the discussion in the field of educational research informed by value-driven and interdisciplinary approaches such as ESD. The research question that will guide our systematic review is as follows: Is there any empirical evidence in the literature that decision-making is promoted through the integration of sustainability-related issues in extended education activities? 


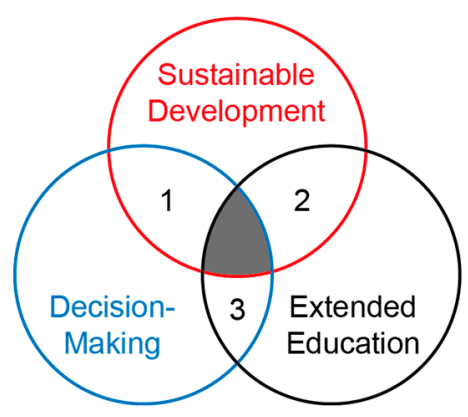

Figure 1. Graphical illustration of this paper's underlying research interest (grey space) combining (1) decision-making in sustainability-related issues (2) sustainability-related issues in extended education activities and (3) decision-making in extended education activities.

\section{Methodology}

The systematic literature review was conducted according to the methodological guidelines in the Cochrane Handbook for Systematic Reviews of Interventions [68]. Furthermore, the procedure of identification and selection of relevant articles was guided by the preferred-reporting of items for systematic reviews and meta-analyses statement (PRISMA; $[69,70]$ ). The resulting PRISMA flowchart illustrates the different phases of the selection process (see Figure 2) through reasoned inclusion and exclusion criteria (see Table 1). Data was collected from three electronic databases, two international ones and a German database, each fitting the interest of the underlying research endeavor: (1) Education Resources Information Center (ERIC), as an internationally recognized database for educational research, and (2) Web of Science (WoS), as a supplementary database focusing on scientific research to assure a holistic approach to the concept of sustainability. To encompass a German perspective, we performed a separate search with German translations of the search terms in (3) FIS Bildung, the German equivalent to ERIC.

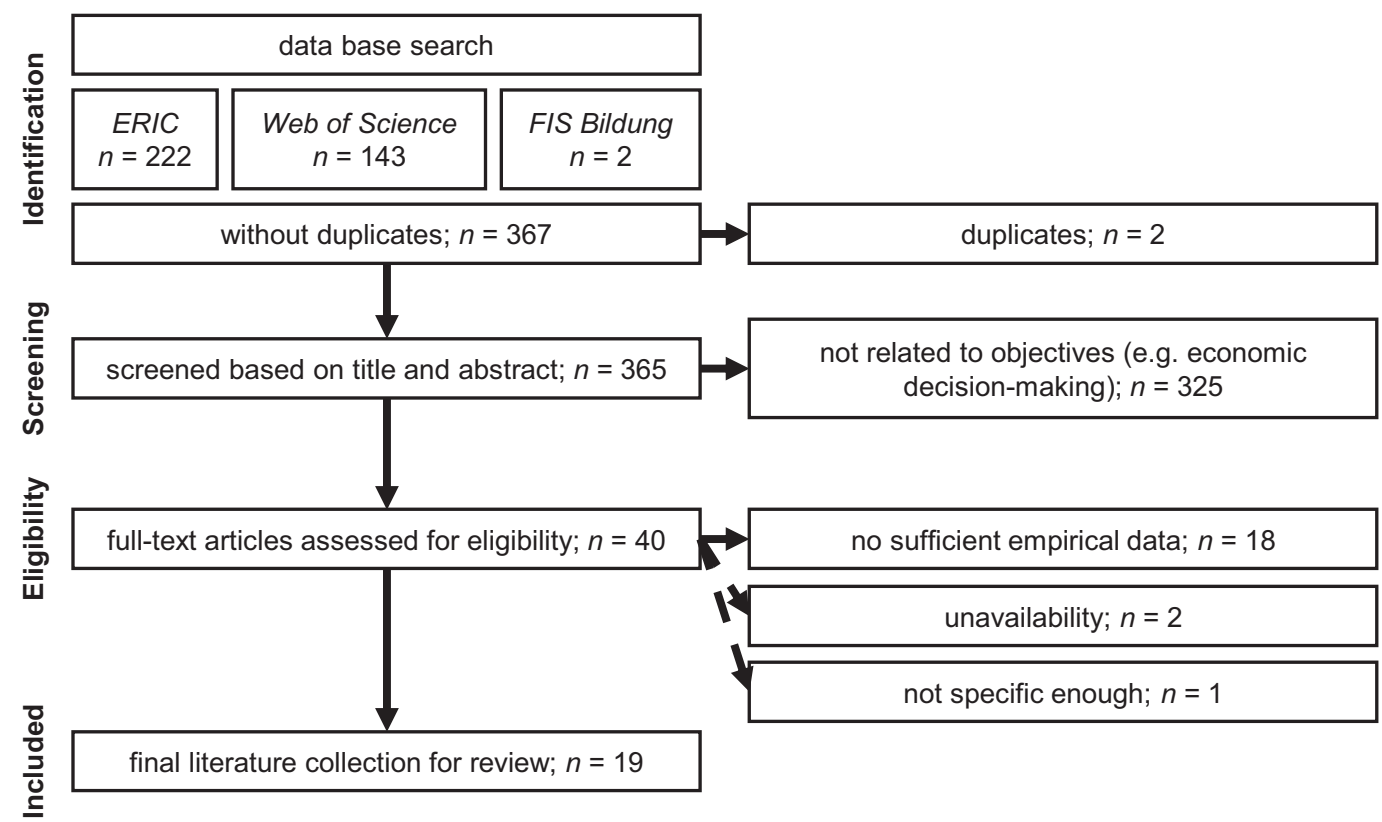

Figure 2. Preferred-reporting of items for systematic reviews and meta-analyses (PRISMA) flowchart of the article selection process.

The validity of results in a systematic literature review depends on the selection of search terms and databases. In order to establish the results' validity the three key search terms extended education, sustainable development and decision making were based on theoretical considerations and expanded 
with terms found to be used interchangeably in other peer-reviewed papers. Following this manner, the search terms were optimized to find all relevant papers without generating an unmanageable number of search results. The selection of databases accounted for discipline-general (WoS) and discipline-specific (ERIC, FIS) publications on an international (ERIC, WoS) as well as national level (FIS). Limits to the validity are discussed in the limitations section (see Section 5.2.). Individual syntaxes were developed and used for each database. For exemplary reasons, one of the syntaxes is shown below.

ERIC on the fifth of December, 2017 (222 articles):

("out-of-school" OR "non-formal learning" OR "informal learning" OR "extracurricular" OR "extended education" OR "outside school" OR "learning outside the classroom" OR "after-school" OR "enrichment") + descriptor: ("sustainable development" OR "sustainability" OR "education for sustainable development" OR "socio-scientific issue" OR "environmental") + abstract: ("decision-making") - educationlevel: ("higher education" OR "university" OR "early childhood" OR "postsecondary education" OR "pre-school" OR "adult basic education" OR "two year colleges" OR "early childhood education" OR "adult education" OR "preschool education" OR "kindergarten").

The final database search was performed in December, 2017. In order to assure a sufficient quality, only peer-reviewed articles were included in this review [71]. In total, 367 articles were obtained containing two doubles. Thus, the search identified 365 unique articles. The abstracts (including keywords if used) of 365 articles were screened twice applying the beforehand defined exclusion criteria which were deductively drawn upon the definitions given in the theoretical background. In case of insufficient or vague abstracts the entire paper was browsed.

Table 1. Inclusion and exclusion criteria for the selection of relevant articles.

\begin{tabular}{lll}
\hline \multicolumn{1}{c}{ Criterion } & \multicolumn{1}{c}{ Inclusion } & \multicolumn{1}{c}{ Exclusion } \\
\hline Extended Education & $\begin{array}{l}\text { Particular activities or methods to expand } \\
\text { the regular curriculum inside or outside } \\
\text { the classroom setting, school bound }\end{array}$ & $\begin{array}{l}\text { Outdoor or environmental education } \\
\text { offerings not related to the wider } \\
\text { school context }\end{array}$ \\
\hline Decision-making & Educational context & $\begin{array}{l}\text { Economical context } \\
\text { (e.g., PROMETHE strategy) }\end{array}$ \\
\hline Sustainable Development & $\begin{array}{l}\text { Activities addressing environmental, } \\
\text { economic or social sustainable } \\
\text { development with focus on individuals }\end{array}$ & $\begin{array}{l}\text { Sustainable development with focus on } \\
\text { institutions (e.g., policies) }\end{array}$ \\
\hline Focus & $\begin{array}{ll}\text { Students } \\
\text { Age }\end{array}$ & $\begin{array}{l}\text { Teachers, parents, development of } \\
\text { an instrument }\end{array}$ \\
\hline Language & Primary to end of school & Kindergarten, university, adult education \\
\hline Type of article & English and German & Other languages \\
\hline
\end{tabular}

Using the criteria above, 40 of the 365 articles fitted the eligibility set of this research endeavor. Two papers [72,73] were not available, despite being requested through different platforms. Hence, 38 papers were analyzed in this literature review. These papers were read carefully and for several times by the first author of this paper and relevant data from each paper was extracted and filled into the Critical Review Forms designed by Law et al. [74] and Letts et al. [75], a form commonly used for systematic literature reviews (e.g., [76,77]). Hence, a rigorous and precise data collection of all 38 papers was assured. Furthermore, by using these standardized review forms the subjectivity during the selection and analysis process was minimized and reliability was enhanced. Using these review forms enabled us to detect studies of insufficient quality during an early stage and reduced the risk of analyzing the studies' results selectively. After this detailed examination, 18 studies could be eliminated based on their poor empirical data. This most frequently included the mere description of educational exercises and games (e.g., [78]). The final selection for this systematic 
literature review yielded 19 articles with a good overall quality and all of which are displaying an overlap of the three components drawn upon in the theoretical derivation. The corresponding table can be found in the appendix (see Table A1).

\section{Results and Discussion}

All of the identified papers $(n=19)$ share a common intersection of the three components. This, in a first step, affirms evidence in the literature that there are studies that display the consideration of decision-making within ESD-related extended education activities. However, while analyzing each paper individually, a study-dependent and predominant concentration on one of the three components (either SD, decision-making or extended education activity) was noticeable. In other words, one of the three components was more central for the interest, course and results of the study than the others. Consequently, the results and discussion section of this review follows an analytical course by splitting the identified studies into three groups; whereas each of the groups is defined by their main emphasis. Furthermore, each group will then be presented with a focal point on decision-making, since all of the studies highlighted decision-making as a variable of interest. The analytical proceeding that we will follow within this section accentuates the assumption that comprehending each individual component is crucial in order to coherently understand the bigger picture [79]. However, we likewise want to acknowledge that "the whole is certainly more than the sum of its parts" [79] (p. 165) which we want to emphasize through brief considerations regarding the component's interplay in the beginning of each paragraph. For a visible distinction between identified articles and other references, the references of identified articles are marked by an asterisk.

\subsection{Surface Characteristics of the Reviewed Papers}

The majority of studies was conducted in Europe $(n=13$, Germany [80-84], United Kingdom [85,86] Cyprus [87,88], Israel [89], the Netherlands [90], Czech Republic [91], and Spain [92]), followed by studies from North America ( $n=4$, America [93-95] and Canada [96]). There was a scattering of studies from Asia ( $n=1$, Singapore [97]) and Oceania ( $n=1$, Australia [67]).

Most studies collected their data from students attending upper secondary education ( $n=9[67,80-82,84,86,87,92,93])$. These students are typically 15 to 18 years old and in grade 9 to 12 . Studies that were undertaken in lower secondary education $(n=7$ [87-89,91,94-96]) comprised students aged 11 to 14 belonging to grade 6 to 8 . One study was conducted in a primary school $(n=1$ [85]) with children aged 7-12. There was also one study that had no information on the participants' age [90] and one study that conducted data from children belonging to upper as well as lower secondary education [97].

Half of the papers followed a qualitative research design $(n=9[80,82,85,91,92,94-97])$. Seven papers $(n=7[83,86-90,93])$ used a pre-post-test design with intervention and three articles $(n=3[80,81,84])$ chose a pre-post-follow up with control group test design.

\subsection{Studies with a Focus on Decision-Making_Decision-Making as Quantitatively Measureable Competence}

Most papers $(n=14)$ predominantly object to model decision-making as a quantitatively measurable competence and therefore focus on decision-making as a competence itself. Within these papers sustainable development, as a thematic circumstance, and the specific integration within an extended education offering constitute the contextual framework. Nonetheless, for the studies' interest and design both components are of minor importance. In this group of papers, three major interests in decision-making were identified: (1) its development; (2) the assessment of its quality; and (3) its inherent structure. The following statement stands exemplarily for papers with this focus: "Decision-making competence refers to the ability to systematically evaluate possible courses of action and [...] to systematically make a final decision" [80] (p. 734).

Papers with this focus $(n=14[67,80-84,86-88,90,92-95])$ define decision-making as a competence required in the process of reasoning. Derived from this perception as a competence, decision-making 
appears to be investigable in its structure and development. Resulting from this developmentally understanding, decision-making seems to be further assessable in its quality. These preliminary assumptions will be examined in the following.

The majority of papers within this subsection $(n=8[80,81,83,84,86,87,90,93])$ explore the effect of specific methods, strategies or approaches on the development of decision-making. Hereby, decision-making competence is described on a latent continuum with separate and differing levels [98]. Based on this separation into independent levels, and the possibility to develop from one level to the other, decision-making is handled as a measurable variable. Gresch, Hasselhorn and Bögeholz [84], for example, explore the effect of particular strategies on students' decision-making. Additionally, they investigate if aspects of self-regulated learning, implemented through the use of a computer-based training program, can assist this process. The results indicate that participants who received a training with elements of self-regulated learning show greater and sustained benefits regarding (1) the inclusion of metadecision aspects, such as structuring and planning the decision-making processes, as well as (2) the reflection on others' decision-making processes. From this illustrative study, where the development of decision-making is measured in turns of achieving higher competence levels, we can underpin our prior statement that decision-making is handled as a measurable variable. This understanding leads us to the aspect of assessment.

A few papers of this subcategory $(n=2[67,82])$ use pedagogical units to assess the quality of students' decision-making. The interventions presented in these articles are not aiming at the promotion of decision-making in the sense of reaching a higher competence level, but solely focus on evaluating its present quality. For instance, Belova, Eilks and Feierabend [82] use different types of role-play on climate change to evaluate students' quality of argumentation. They therefore rate each of the arguments used in the role-play in three main categories (domain, level and reference). In order to assess the quality of decision-making, their second category (level) describes the argument's complexity in gradual levels from zero (not related to the topic) to five (elaborated). While investigating their collected data through the application of each category, Belova, Eilks and Feierabend [82] were able to analyze each argument in detail. As a result of their study, they identified role-play as an opportunity to mimic societal debating and to assess decision-making in its inner quality. In formal education, tools for students' assessment are an essential for teachers since grading takes up an elemental part of their tasks [99]. This should not be taken lightly; the effect of grades on students' self-concept is already shown [100]. With regards to current findings from Steffen and Hößle [101] further research into the assessment of students' decision-making is needed. Concluding from their paper, teachers have trouble in diagnosing and evaluating students' decision-making and rather perform a negated coping. This means that teachers question their ability to diagnose decision-making even though their capability is confirmed [101]. Further assessment tools could therefore help practitioners to encourage and gauge students' decision-making and to purposively incorporate supportive activities into their lesson planning. That only two of the identified papers within this subcategory address the assessment of students' decision-making can be explained by this paper's underlying research interest. While we were particularly looking for extended education offerings, these are, in most cases, ungraded [65].

In contrast to the development or the quality of decision-making, some papers $(n=4[88,92,94,95])$ concentrate on its structural composition. Paraskeva-Hadjichambi, Hadjichanmbis and Korflatis [88], for example, are interested in the role of values and how these are interlinked when making decisions. In their perspective, the ability to prioritize different criteria and to expose the underlying values might be a suitable way to deal with SSIs. This assumption, that values pose an immanent element for the settlement of SSIs, is long-established [102] and several research practitioners are shedding the light on an ethical dimension within decision-making [103-106].

Concluding these deliberations, three major interests in decision-making were presented: (1) its development; (2) the assessment of its quality; and (3) its inherent structure. Based on these interests, decision-making is understood as a measurable competence. Interestingly, in the papers identified in this subsection, decision-making is presented as a practice that mainly takes place within 
an individual's cognition in the sense of a systematic proceeding. Questions regarding an explicit integration of others, for example through an evoked change in perspectives, remain open. Especially in the light of our globalized and multicultural society the explicit promotion of multiple perspectives appears necessary to foster a sustainable development [107].

\subsection{Studies with a Focus on Extended Education Activities-Decision-Making as Participation in Change}

Some papers $(n=3)$ pay particular attention to the educational embodiment within which decision-making is explored. This means the specific characteristics of the activity are setting the fundamental basis that enables a development of decision-making. Sustainable development is, again, providing the thematic context which could be ousted by another real-world, ill-defined and urging issue such as the use of animal research. In this group of studies, the students' participation in change, which is offered through the facilitation of an extended education activity, was identified as main outcome with regards to decision-making. The following statement stands exemplarily for papers with this focus: "Rather than preparing for a life after school or for future science courses, children already participated in and contributed to social life in the community" [96] (p. 273).

Three articles $([89,96,97])$ focus on how the educational engagement in real-world problem-solving activities can empower students to make decisions and thus to get involved in civic matters. Here, the educational context of the extended education activity is in the foreground. The paper written by Roth \& Lee [96], for instance, permits an insight into a case study developing a science education model that takes scientific literacy into the local community. Based on a 3-year, multisite ethnographic research project, the authors illustrate a "rethinking of science education" (p. 263). Here, the students were required to get actively engaged in a local socio-scientific issue. After practicing scientific procedures inside the classroom, students conducted their own research in and along a creek's watershed. Students then presented their findings to other school classes and during an environmental event. In this sense, the educational content of water quality and related problems were broadened from the classroom into the real-world community context. During this problem-solving process the community was involved twofold: on one hand, they were actively involved by assisting students' research activities and on the other hand, they were also intertwined in a more personal way since water quality-related problems were an urging community concern.

In all three papers of this subcategory, the embodiment of the community and local places seems to be a joint feature. From an instructional perspective, this draws attention to an approach called place-based education. In place-based education the primary interest lies in the interconnectedness of local places, the community and educational activities [108]. The underlying pedagogical concept of place-based education can be traced back to John Dewey [109] who campaigned for an extension of methods in the back then contemporary education. In his understanding, educational experiences that are interwoven with the local environment enable students the connection of their academic and personal life. This accentuation on contextualized learning, where theoretical content can be associated with the personal life, remains the fundamental aspect of place-based education to this day $[108,110]$. Expanding this understanding, Gruenewald, Koppelman and Elam [111] spotlight an applied dimension of place-based education. In their deliberation, the inclusion of the local environment equally enables a centering of the human-nature relationship. Through the interaction with local places, and ergo their construction and destruction, students are able to experience the human impact on the environment. This experience, according to Gruenewald and Smith [112], can enhance students' participation in civic decision-making since places hereby create "contexts for the practice of democracy" [111] (p. 235).

The papers identified in this subcategory highlight a further aspect worth discussing. Teaching within the context of sustainability and with the aid of teaching material is often interlinked with a simplification of the issue [113]. According to Holfelder [113], in simplified learning material students are commonly seen in a one-dimensional role of consuming individuals. In other words, students are perceived as individuals that can solely act upon existing processes and thus 
decide between different options of consumption (e.g., to buy fast-fashion or fair-trade clothes). Contrarily, in the papers identified in this subcategory decision-making goes beyond the request to merely choose between different options. Here, the relocation of a problem-solving task into a real-world community context through extended education activities adds an active dimension and can lead to a serious change on a civic and maybe even a political level. This promotes an understanding of students as active citizens shaping our society. According to Akin, Calik and Engin-Demir [114], the promotion of active citizenship through shared decision-making can further be regarded as essential to maintain and improve a democratic culture. This critical-democratic notion of citizenship supports students' enquiring attitude to creatively address pressuring and complex issues [61]. The promotion of such activating perceptions seems necessary for the enabling of a sustainable future [115].

\subsection{Studies with a Focus on the Context of SD-Decision-Making as Empowerment}

Two of the articles $[85,91]$ deliberately set their research in the context of SD. The involvement with this particular context is understood as a potential stage that empowers students to express themselves. Without a steered learning goal, the educational context of the activity is located in the background. Rather than putting subject-based learning content across, the extended education activity within the ESD is understood as "space for transformative social learning" [116] (p. 388). In this group of studies students' empowerment was recognized as chief finding with regards to decision-making. The following statement stands exemplarily for papers with this focus: "Another feature of education for sustainable development is the use of a learner-centered and democratic approach that empowers students to address real world issues." [85] (p. 12).

The paper by Mannion [85] develops a typology that categorizes Scottish school students' involvement in decision-making processes and their resulting participation in a playground development. The typology reveals a wide-ranging perception of children's ability to engage in decision-making. This ranges from barely any participation, for example because of safety reasons, to great autonomy allowing them their private space separated from obvious adult supervision. Decision-making in both papers of this subsection is understood as children's empowerment to make their voice heard. Concluding from this, children are seen as serious members of the decision-making body and corresponding processes. This understanding, participation in decision-making as empowerment, is an integral part of ESD [117].

The authors' selection of qualitative research designs and explorative research instruments, in both papers, seems reasonable to holistically capture children's opinions and thoughts [118]. Despite that, it is highly important to consider that depending on the research question one might not measure an objective reality, but rather participants' construction of it. As an example, the paper by Cincera and Kovacikova [91] explores how students experience being a member of an environmental school group and how they reflect on their involvement. As noted by the authors, the data collected in this study does not display the actual working processes of the environmental program, but rather mirrors participants' subjective perception. Nevertheless, the direct participation in the discussion and solution of environmental issues through the involvement in the school's environmental group underlines, again, an enabling perception of students. This goes in line with James and Prout [119], who state that young people have to be seen as capable and responsible social actors with their own mind and voice. Especially in the context of sustainable development and related environmental, social and economic issues that will occur in the future, the serious recognition of later generations appears crucial [115]. Well-planned activities with a thematic focus on SD, such as the environmental school group, can hence be seen as a valuable opportunity to empower students as independent and capable actors willing to take responsibility for our future.

\section{Conclusions}

A goal of this study was to identify ESD-related extended education offerings and their contributions to students' decision-making. Using the search syntaxes, a total of 365 peer-reviewed 
journal articles were found in December 2017. After skimming available abstracts and corresponding keywords, 38 full-text articles were evaluated for eligibility. The final selection yielded 19 articles for this systematic literature review. The common intersection of the three components: sustainable development, extended education offering and students' decision making is evident in all of the identified papers. This affirms the initial research interest in a common overlap in the existing literature. Nevertheless, an unequal distribution of the studies' research interests was noticed. Most papers particularly target decision-making, framing it as a quantitatively measurable competence. Here, three major interests in decision-making were identified: (1) its development; (2) the assessment of its quality; and (3) its inherent structure. Studies that chiefly focused on the educational aspect, namely the extended education activity, highlighted the educational framework which is needed in order to enable the development of decision-making. In these papers, decision-making was understood as students' participation in change. In the last group of studies, concentrating on the component of $\mathrm{SD}$, the specific theme was seen as a successful platform for students to use decision-making in order to express their thoughts and opinions.

\subsection{The Gap-Students' Decision-Making in ESD-Related Extracurricular Education}

Despite the papers' common area of interest, each paper can be positioned as focused on only one of the three components, with the other components serving as a backdrop. Resulting from this observation, none of the papers seems to display an equal distribution of attention. This, however, needs to be viewed critically, because integrating sustainability-related issues in an extended education activity displays a promising learning opportunity to optimally foster students' decision-making. Up to the present day, questions concerning sustainable development are difficult to integrate into subject-based lessons [50]. Extended education activities have thus been argued to constitute a highly suitable and more holistic platform to process complex and multidiscipline topics such as SD [54]. The multidisciplinary character of sustainability-issues can hereby foster decision-making which is required when processing questions that pose complex and pressuring decision situations for today's and future generations [37].

The differing foci found instead might be explained by looking at the scientific origin of each component. Whereas extended education has roots in the educational research sector [120], the concept behind decision-making has its origins in cognitive psychology [1]. Sustainability, in contrast, has its thematic core equally in the natural and social sciences, due to its holistic and multifaceted nature [38]. A study displaying an equal distribution of all three components would accordingly require a balanced deliberation of diverse disciplines. In contrast to this multifacetedness, being a researcher is often equated with being an expert in a precise field. This circumstance might partly explain the lack of papers that are locatable in the joint center of the three components.

Although we put forward a strong theoretical argument for the integration of sustainability-related issues in extended education activities to promote decision-making, our literature review could not reveal any studies with empirical evidence for this argument. We therefore suggest further research to address this interrelation in order to support our argument empirically.

\subsection{Limitations}

A limitation of this review is its little contribution to the discussion concerning values and ethics; even though moral aspects are an acknowledged facet of decision-making. Retrospectively, we would suggest adding appropriate terms to the syntaxes, such as moral judgement, in order to ensure the identification of relevant papers. Furthermore, review articles are typically constrained by a publication bias. This means that research reporting statistically significant effects is more often published than papers reporting non-significant effects [121]. Writing a systematic review conclusively underlies the journals' pre-selection of articles. The conduction of a meta-analysis might have 
controlled this bias; nevertheless, since a large proportion of the papers are subject to a qualitative research design this endeavor did not seem suitable.

Apart from the mostly optional participation in early childhood education offerings, the national school system constitutes the baseline of collectively received education. As shown within this paper, besides the regular and compulsory school hours, extracurricular activities have become a valuable element of students' school life [122]. The development and support of decision-making is, nevertheless, also addressed through curricular activities. However, these studies were not addressed due to our interest in extended education activities and the subsequent development of specific search terms. We therefore want to acknowledge that much work that is done by other prominent research groups in the field of decision-making fell short in reference (e.g., [123-126]).

\section{Implications}

Further research value is seen in the conduction of studies that are set within the equal distribution of all three components, since it is assumed that promoting students' decision-making is optimally performed in ESD-related extracurricular activities dealing with interdisciplinary and socio-scientific issues such as SD. In addition, we assume that the exploration of decision-making's differing notions would be beneficial to gain further insight into its inherent construction. This includes the conceptualization as (1) a systematic process that chiefly takes place within the spectrum of personal reasoning (e.g., [98]) and as (2) a competence that explicitly embraces the consideration of other's values and perspectives (e.g., [125]).

For educational practice, two main implications can be drawn upon this literature review. The first suggestion addresses the planning and implementation of learning activities. While advocating that students perform as critical citizens in ESD-related issues, practitioners equally need to provide an adequate educational context. This implication might be of a structural nature, such as allowing students the time and space to enquire into self-chosen environmental, economic or social problems within their local environment. It might also imply acquiring new subject knowledge to jointly explore and discuss students' solution approaches. The empowerment of students' learning in ESD-related issues can thus transform practitioners themselves into agents of change [127]. Secondly, whenever learning activities are implemented, they are perceived within one's personal frame of reference [128]. Sustainable development can hereby operate as a doorway to modify these frames, since conflicting values, beliefs and interest can support a critical discourse amongst students [129]. Even though no empirical evidence has been found yet, we would like to encourage practitioners to implement ESD-related extracurricular activities in order to promote students' decision-making and a sustainable dialogue.

Education remains one of the key elements for civic participation. Educational approaches, such as ESD, thus build a fundamental platform for the discussion and creation of ideas that lead to informed decisions and actions. We therefore want to emphasize the importance of ESD and connected activities, since this surely will be crucial for the maintenance of a well-functioning and open-minded society that is capable of dealing with the environmental, social and economic challenges that lie ahead of us. In the end, students are the future's hope and we should try our best to equip them with competences to jointly make decisions for a more sustainable and just world.

Author Contributions: Conceptualization: C.G. and U.H.; methodology, C.G. and T.B.; formal analysis, C.G.; investigation, C.G.; data curation, C.G.; writing-original draft preparation, C.G.; writing-review and editing, C.G., T.B. and U.H.; supervision, T.B. and U.H.

Funding: This research received no external funding.

Acknowledgments: We would like to express our sincere appreciation to the three reviewers.

Conflicts of Interest: The authors declare no conflict of interest. 


\section{Appendix A}

Table A1. A summary of the qualified literature.

\begin{tabular}{ccl}
\hline \multicolumn{1}{c}{ Study } & $\#$ & \multicolumn{1}{c}{ Purpose } \\
\hline de Jager, H. \& van der Loo, F. (1990) & {$[90] \quad \begin{array}{l}\text { The study evaluates two learning units } \\
\text { with regards to their effect on students' } \\
\text { decision-making. }\end{array}$} \\
\hline Dori, Y.J. \& Tal, R.T. (2000) & [89] & $\begin{array}{l}\text { The study explores the effect of a } \\
\text { collaborative learning project on students' } \\
\text { environmental attitude and knowledge as } \\
\text { well as their decision-making skills. }\end{array}$ \\
\hline Jimenez-Aleixandre, M. (2002) & [92] & $\begin{array}{l}\text { The study explores the aspects of } \\
\text { knowledge and skills required to address } \\
\text { a SSI and to make informed decisions } \\
\text { about it. }\end{array}$ \\
\hline
\end{tabular}

Roth, W. \& Lee, S. (2004)

[96] The study purposes to redefine scientific literacy in favour for a social component. Students' willingness to use energy more carefully declines if energy conservation would cost money or reduce comfort.

Environmental knowledge and attitude as well as higher-order thinking skills improved significantly over the course of the learning project $(p<0.0001)$.

By comparing the warrants used by students and used by the expert, a rich overlap in its content is displayed. Therefore, students are seen as active knowledge producers. Scientific literacy is characterized through social rather than individual activities. Science education has to be seen 'as' and 'for' participation in the community.

Derivation of five types of participation practice:

The Outdoor Classroom

Mannion, G. (2005)

[85] This study designs a typology of practice

Practices of a Safe Childhood school ground developments.

Practices of the Tribal Child

Practices of Community

Practices of Citizenship and Sustainability.

The group using the computer

The study examines the effect of a
computer program on students'

Siegel, M.A. (2006) decision-making and reasoning in a sustainability-related context. program has better posttest scores (partially) than the control group regarding the use of evidence when making decisions.

The study explores the effectiveness of a

A comparison of pre- and posttest comments reveals a general shift to

Grace, M. (2009) group discussion approach on students' decision-making in a sustainability-related context. higher-level responses subsequent to the discussions.

Nicolaou, C.T., Korfiatis, K., The study examines students Students' decision-making improved through the learning development of decision-making and Evagorou, M. \& [87] environmental concern with aid of activity $(p<0.001)$ with a larger gain environmental concern with aid in score among the high learning activities. performing group.

\section{Levine Rose, S. \&}

Calabrese Barton, A. (2012)

The study aims to understand how students frame their decision about SSIs such as building a power plant.

Findings support the use of frames as conceptual tools and shed light on the importance of personal experiences when making decisions.

Through the implementation of a computer-based intervention, this study

Gresch, H. \& Bögeholz, S. (2013).

[80] investigates the effect of decision-making strategies on decision-making in the context of sustainability.

Using knock-out criteria when making a decision was found to be more comfortable for students than performing a full trade-off.

Gresch, H., Hasselhorn, M. \&

The study examines the effects of

Bögeholz, S. (2013) decision-making strategies on students' decision-making in sustainability-related contexts.

The treatment group of this study was significantly better than the control group in describing the presented decision-making strategies $(p<0.001)$. 
Table A1. Cont.

\begin{tabular}{|c|c|c|c|}
\hline Study & $\#$ & Purpose & Selected Outcomes \\
\hline Kim, M. \& Tan, H. (2013) & [97] & $\begin{array}{l}\text { This study explores possibilities for } \\
\text { interdisciplinary problem-solving } \\
\text { processes among secondary school } \\
\text { children using environmental challenges. }\end{array}$ & $\begin{array}{l}\text { The relevance and certainty of } \\
\text { information as well as the } \\
\text { development of respectful } \\
\text { relationships were taken as } \\
\text { important criteria for students' } \\
\text { joint decision-making. }\end{array}$ \\
\hline $\begin{array}{l}\text { Paraskeva-Hadjichambi, D., } \\
\text { Hadjichanmbis, A. \& } \\
\text { Korfiatis, K. (2015) }\end{array}$ & [88] & $\begin{array}{l}\text { The study aims to explore how students' } \\
\text { decisions are interlinked with their } \\
\text { personal values. }\end{array}$ & $\begin{array}{l}\text { SSIs' social dimension was an } \\
\text { important factor for } \\
\text { students' decision-making. }\end{array}$ \\
\hline Dawson, V. \& Carson, K. (2017) & [67] & $\begin{array}{l}\text { The study explores the effectiveness of } \\
\text { SSI-scenarios to assess students' } \\
\text { decision-making and } \\
\text { argumentation skills. }\end{array}$ & $\begin{array}{l}\text { The developed scenarios are } \\
\text { suitable to assess the quality of } \\
\text { students' argumentation skills. }\end{array}$ \\
\hline $\begin{array}{l}\text { Eggert, S., Nitsch, A., Boone W., } \\
\text { Nückles, M. \& Bögeholz, S. (2017) }\end{array}$ & [83] & $\begin{array}{l}\text { The study investigates concept mapping } \\
\text { as a learning strategy in order to promote } \\
\text { students' decision making in the context } \\
\text { of sustainability. }\end{array}$ & $\begin{array}{l}\text { Equipping students with relevant } \\
\text { concepts is highly beneficial for } \\
\text { their conceptual knowledge. } \\
\text { Enabling students free mapping } \\
\text { conditions is highly beneficial for } \\
\text { their argumentation. }\end{array}$ \\
\hline $\begin{array}{l}\text { Gresch, H., Hasselhorn, M. \& } \\
\text { Bögeholz, S. (2017) }\end{array}$ & [84] & $\begin{array}{l}\text { This study examines the effect of } \\
\text { decision-making strategies, combined } \\
\text { with reflections on others' } \\
\text { decision-making processes, on students' } \\
\text { decision-making in the context of } \\
\text { sustainability. Moreover, the elements of } \\
\text { self-regulated learning are from interest. }\end{array}$ & $\begin{array}{l}\text { Self-regulated learning has a } \\
\text { positive effect on } \\
\text { students' decision-making. }\end{array}$ \\
\hline
\end{tabular}

\section{References}

\section{References marked with an asterisk indicate studies included in the systematic literature review.}

1. Wang, Y.; Ruhe, G. The Cognitive Process of Decision Making. Int. J. Cogn. Inform. Nat. Intell. 2007, 1, 73-85. [CrossRef]

2. Zeidler, D.L.; Sadler, T.D.; Simmons, M.L.; Howes, E.V. Beyond STS: A research-based framework for socioscientific issues education. Sci. Educ. 2005, 89, 357-377. [CrossRef]

3. Stefanou, C.R.; Perencevich, K.C.; DiCintio, M.; Turner, J.C. Supporting Autonomy in the Classroom: Ways Teachers Encourage Student Decision Making and Ownership. Educ. Psychol. 2004, 39, 97-110. [CrossRef]

4. Haidt, J. The new synthesis in moral psychology. Science 2007, 316, 998-1002. [CrossRef] [PubMed]

5. Kahneman, D. Thinking, Fast and Slow; Penguin: München, Germany, 2012.

6. Wilson, R.; Keil, F. MIT Encyclopedia of the Cognitive Sciences; MIT Press: Cambridge, UK, 2001.

7. Ajzen, I. The theory of planned behavior. Organ. Behav. Hum. Decis. Process. 1991, 50, 179-211. [CrossRef]

8. Ajzen, I.; Fishbein, M. The Prediction of Behavior from Attitudinal and Normative Variables. J. Exp. Soc. Psychol. 1970, 6, 466-487. [CrossRef] 
9. Wood, W.; Quinn, J.M.; Kashy, D.A. Habits in everyday life: Thought, emotion, and action. J. Pers. Soc. Psychol. 2002, 83, 1281-1297. [CrossRef] [PubMed]

10. Webb, T.L.; Sheeran, P. Does changing behavioral intentions engender behavior change? A meta-analysis of the experimental evidence. Psychol. Bull. 2006, 132, 249-268. [CrossRef] [PubMed]

11. Mager, U.; Nowak, P. Effects of student participation in decision making at school. A systematic review and synthesis of empirical research. Educ. Res. Rev. 2012, 7, 38-61. [CrossRef]

12. Siribunnam, S.; Nuangchalerm, P.; Jansawang, N. Socio-scientific decision making in the science classroom. Int. J. Cross-Discipl. Subj. Educ. 2014, 5, 1777-1782.

13. Lee, Y.C.; Grace, M. Students' reasoning processes in making decisions about an authentic, local socio-scientific issue: Bat conservation. J. Biol. Educ. 2010, 44, 156-165. [CrossRef]

14. Saunders, K.J.; Rennie, L.J. A Pedagogical Model for Ethical Inquiry into Socioscientific Issues In Science. Res. Sci. Educ. 2013, 43, 253-274. [CrossRef]

15. Sadler, T.D. Informal reasoning regarding socioscientific issues: A critical review of research. J. Res. Sci. Teach. 2004, 41, 513-536. [CrossRef]

16. Sadler, T.D. (Ed.) Socio-Scientific Issues in the Classroom: Teaching, Learning and Research; Springer: Dordrecht, The Netherlands, 2011.

17. Zeidler, D.L.; Walker, K.A.; Ackett, W.A.; Simmons, M.L. Tangled up in views: Beliefs in the nature of science and responses to socioscientific dilemmas. Sci. Educ. 2002, 86, 343-367. [CrossRef]

18. Sadler, T.D.; Romine, W.L.; Topçu, M.S. Learning science content through socio-scientific issues-based instruction: A multi-level assessment study. Int. J. Sci. Educ. 2016, 38, 1622-1635. [CrossRef]

19. Kolsto, S.D. 'To trust or not to trust, ... '-pupils' ways of judging information encountered in a socio-scientific issue. Int. J. Sci. Educ. 2001, 23, 877-901. [CrossRef]

20. Zeidler, D.L.; Lewis, J. Unifying themes in moral reasoning on socioscientific issues and discourse. In The Role of Moral Reasoning on Socioscientific Issues and Discourse in Science Education; Zeidler, D.L., Ed.; Kluwer Academic Publishers: Dordrecht, The Netherlands, 2003; pp. 289-306.

21. Dawson, V.; Venville, G. Introducing High School Biology Students to Argumentation About Socioscientific Issues. Can. J. Sci. Math. Technol. Educ. 2013, 13, 356-372. [CrossRef]

22. Driver, R.; Newton, P.; Osborne, J. Establishing the norms of scientific argumentation in classrooms. Sci. Educ. 2000, 84, 287-312. [CrossRef]

23. Sadler, T.D.; Barab, S.A.; Scott, B. What Do Students Gain by Engaging in Socioscientific Inquiry? Res. Sci. Educ. 2007, 37, 371-391. [CrossRef]

24. Ratcliffe, M.; Grace, M. Science Education for Citizenship: Teaching Socio-Scientific Issues; Open University Press: Maidenhead, UK, 2003.

25. Levy Nahum, T.; Ben-Chaim, D.; Azaiza, I.; Herskovitz, O.; Zoller, U. Does STES-Oriented Science Education Promote 10th-Grade Students' Decision-Making Capability? Int. J. Sci. Educ. 2009, 32, 1315-1336. [CrossRef]

26. Ardoin, N.M.; DiGiano, M.L.; O'Connor, K.; Podkul, T.E. The development of trust in residential environmental education programs. Environ. Educ. Res. 2017, 23, 1335-1355. [CrossRef]

27. Sadler, T.D. Situated learning in science education: Socio-scientific issues as contexts for practice. Stud. Sci. Educ. 2009, 45, 1-42. [CrossRef]

28. Cebrián, G.; Junyent, M. Competencies in Education for Sustainable Development: Exploring the Student Teachers' Views. Sustainability 2015, 7, 2768-2786. [CrossRef]

29. Bond, D.P.; Grasby, S.E. On the causes of mass extinctions. Palaeogeogr. Palaeocl. 2017, 478, 3-29. [CrossRef]

30. Brose, U.; Blanchard, J.; Eklöf, A.; Galiana, N.; Hartvig, M.; Hirt, M.; Kalinkat, G.; Nordström, M.C.; O'Gorman, E.J.; Rall, B.C.; et al. Predicting the consequences of species loss using size-structured biodiversity approaches. Biol. Rev. 2017, 92, 684-697. [CrossRef] [PubMed]

31. Doran, P.; Zimmerman, K. Examining the Scientific Consensus on Climate Change. Eos 2009, 90, $22-23$. [CrossRef]

32. Munday, P.L. New perspectives in ocean acidification research: Editor's introduction to the special feature on ocean acidification. Biol. Lett. 2017, 13, 1-3. [CrossRef] [PubMed]

33. Mathis, J.; Cooley, S.; Yates, K.; Williamson, P. Introduction to this Special Issue on Ocean Acidification: The Pathway from Science to Policy. Oceanography 2015, 25, 10-15. [CrossRef] 
34. Wood, H.E.; Marlin, N.; Mudway, I.S.; Bremner, S.A.; Cross, L.; Dundas, I.; Grieve, A.; Grigg, J.; Jamaludin, J.B.; Kelly, F.J.; et al. Effects of Air Pollution and the Introduction of the London Low Emission Zone on the Prevalence of Respiratory and Allergic Symptoms in Schoolchildren in East London: A Sequential Cross-Sectional Study. PLoS ONE 2015, 10, e0109121. [CrossRef] [PubMed]

35. Swami, A.; Chauhan, D. Impact of air pollution induced by automobile exhaust pollution on air pollution tolerance index (APTI) on few species of plants. Int. J. Sci. Res. 2015, 4, 342-343.

36. Dionisio, K.L.; Frame, A.M.; Goldsmith, M.-R.; Wambaugh, J.F.; Liddell, A.; Cathey, T.; Smith, D.; Vail, J.; Ernstoff, A.S.; Fantke, P.; et al. Exploring consumer exposure pathways and patterns of use for chemicals in the environment. Toxicol. Rep. 2015, 2, 228-237. [CrossRef] [PubMed]

37. Little, A.W.; Green, A. Successful globalisation, education and sustainable development. Int. J. Educ. Dev. 2009, 29, 166-174. [CrossRef]

38. Sartori, S.; Da Silva, F.L.; Campos, L.M.S. Sustainability and sustainable development: A taxonomy in the field of literature. Ambient. Soc. 2014, 17, 1-22. [CrossRef]

39. Leal Filho, W. Dealing with misconceptions on the concept of sustainability. Int. J. Sustain. High. Ed. 2000, 1, 9-19. [CrossRef]

40. Hawkes, J. The Forth Pillar of Sustainability: Culture's Essential Role in Public Planning; Common Ground Publishing: Melbourne, Australia, 2001.

41. Yencken, D.; Wilkinson, D. Resetting the Compass: Australia's Journey towards Sustainability; CSIRO Publishing: Collingwood, Australia, 2000.

42. Vare, P.; Scott, W. Learning for a Change: Exploring the relationship between education and sustainable development. J. Educ. Sustain. Dev. 2007, 1, 191-198. [CrossRef]

43. United Nations Educational, Scientific and Cultural Organization. Education for Sustainable Development Goals: Learning Objective; United Nations Educational, Scientific and Cultural Organization: Paris, France, 2017.

44. Collier, G. Reflections on sustainability: Questioning the knowing and the doing. Geogr. Educ. 2004, 17, 19-25.

45. Boeve-de Pauw, J.; Gericke, N.; Olsson, D.; Berglund, T. The Effectiveness of Education for Sustainable Development. Sustainability 2015, 7, 15693-15717. [CrossRef]

46. Andersson, K.; Jagers, S.; Lindskog, A.; Martinsson, J. Learning for the Future? Effects of Education for Sustainable Development (ESD) on Teacher Education Students. Sustainability 2013, 5, 5135-5152. [CrossRef]

47. Boehmer-Christiansen, S. The geo-politics of sustainable development: Bureaucracies and politicians in search of the holy grail. Geoforum 2002, 33, 351-365. [CrossRef]

48. Dale, A.; Newman, L. Sustainable development, education and literacy. Int. J. Sustain. High. Ed. 2005, 6, 351-362. [CrossRef]

49. Laurie, R.; Nonoyama-Tarumi, Y.; McKeown, R.; Hopkins, C. Contributions of education for sustainable development (ESD) to quality education: A synthesis of research. J. Educ. Sustain. Dev. 2016, 10, $226-242$. [CrossRef]

50. McKeown, R.; Hopkins, C. Moving Beyond the EE and ESD Disciplinary Debate in Formal Education. J. Educ. Sustain. Dev. 2016, 1, 17-26. [CrossRef]

51. Summers, M.; Childs, A.; Corney, G. Education for sustainable development in initial teacher training: Issues for interdisciplinary collaboration. Environ. Educ. Res. 2005, 11, 623-647. [CrossRef]

52. Sleeter, C.E.; Flores Carmona, J. Un-Standarizing Curriculum: Multicultural Teaching in the Standards-Based Classroom, 2nd ed.; Teachers College Press: New York, NY, USA, 2017.

53. Pittman, K.J.; Irby, M.; Yohalem, N.; Wilson-Ahlstrom, A. Blurring the lines for learning: The role of out-of-school programs as complements to formal learning. New Dir. Youth Dev. 2004, 2004, 19-41. [CrossRef] [PubMed]

54. Noddings, N. Education and Democracy in the 21st Century; Teachers' College Press: New York, NY, USA, 2012.

55. Brundiers, K.; Wiek, A.; Redman, C.L. Real-world learning opportunities in sustainability: From classroom into the real world. Int. J. Sustain. High. Ed. 2010, 11, 308-324. [CrossRef]

56. Rowe, D. Education for a sustainable future. Science 2007, 317, 323-324. [CrossRef] [PubMed]

57. Ha-Brookshire, J.; Norum, P. Cotton and sustainability: Impacting student learning through sustainable cotton summit. Int. J. Sustain. High. Ed. 2011, 12, 369-380. [CrossRef]

58. Winter, J.; Cotton, D. Making the hidden curriculum visible: Sustainability literacy in higher education. Environ. Educ. Res. 2012, 18, 783-796. [CrossRef] 
59. Lipscombe, B.P.; Burek, C.V.; Potter, J.A.; Ribchester, C.; Degg, M.R. An overview of extra-curricular education for sustainable development (ESD) interventions in UK universities. Int. J. Sustain. High. Ed. 2008, 9, 222-234. [CrossRef]

60. National Foundation for Educational Research. Active Citizenship and Young People: Opportunities, Experiences and Challenges in and Beyond School: Research Report No 732. 2006. Available online: https: / / files.eric.ed.gov / fulltext/ED502417.pdf (accessed on 24 October 2018).

61. Veugelers, W. Creating critical-democratic citizenship education: Empowering humanity and democracy in Dutch education. J. Comp. Int. Educ. 2007, 37, 105-119. [CrossRef]

62. Mahoney, J.L.; Cairns, R.B. Do extracurricular activities protect against early school dropout? Dev. Psychol. 1997, 33, 241-253. [CrossRef] [PubMed]

63. Feldman, A.F.; Matjasko, J.L. The role of school-based extracurricular activities in adolescent development: A comprehensive review and future directions. Rev. Educ. Res. 2005, 75, 159-210. [CrossRef]

64. Ecarius, J.; Klieme, E.; Stecher, L.; Woods, J. Extended Education: An International Perspective: Proceedings of the International Conference on Extracurricular and Out-of-School Time Educational Research; Barbara Budrich Publisher: Opladen, Germany, 2013.

65. Stecher, L. Extended Education as Part of the German General Education System: Status quo, Developments, and Policy Issues: Paper Presented at the 3rd Meeting of NEO ER; Sungkyunkwan University: Seoul, Korea, 2014.

66. Lewis, J.; Leach, J. Discussion of Socio-scientific Issues: The role of science knowledge. Int. J. Sci. Educ. 2006, 28, 1267-1287. [CrossRef]

67. * Dawson, V.; Carson, K. Using climate change scenarios to assess high school students' argumentation skills. Res. Sci. Technol. Educ. 2016, 35, 1-16. [CrossRef]

68. Higgins, J.P.T.; Green, S. Cochrane Handbook for Systematic Reviews of Interventions Version 5.1.0. 2011. Available online: www.handbook.cochrane.org (accessed on 24 October 2018).

69. Moher, D.; Liberati, A.; Tetzlaff, J.; Altman, D. Reprint-preferred reporting items for systematic reviews and meta-analyses: The PRISMA statement. Phys. Ther. 2009, 89, 873-880. [PubMed]

70. Moher, D.; Shamseer, L.; Clarke, M.; Ghersi, D.; Liberati, A.; Petticrew, M.; Shekelle, P.; Stewart, L.A. Preferred reporting items for systematic review and meta-analysis protocols (PRISMA-P) 2015 statement. Syst. Rev. 2015, 4, 1. [CrossRef] [PubMed]

71. Korpershoek, H.; Harms, T.; de Boer, H.; van Kuijk, M.; Doolaard, S. A Meta-Analysis of the Effects of Classroom Management Strategies and Classroom Management Programs on Students' Academic, Behavioral, Emotional, and Motivational Outcomes. Rev. Educ. Res. 2016, 86, 643-680. [CrossRef]

72. Naish, M. Decisions, decisions! Teaching and assessing environmental thinking. Geogr. Educ. 1986, 5, 31-34.

73. Randle, D. Ecocabins: Monitoring our impact. Green Teach. 1994, 38, 33-35.

74. Law, M.; Stewart, D.; Letts, L.; Pollock, N.; Bouch, J.; Westmorland, M. Critical Review Form-Quantitative Review Form. 2007. Available online: https:/ / www.unisa.edu.au/Global/Health/Sansom/Documents/ iCAHE/CATs/McMasters_Quantitative\%20review.pdf (accessed on 24 October.2018).

75. Letts, L.; Wilkins, S.; Law, M.; Stewart, D.; Bosch, J.; Westmorland, M. Guidelines for Critical Review form: Qualitative Studies. 2007. Available online: http://www.unisa.edu.au/PageFiles/23703/7B\%20McMasters_ qualreview_version2\%200\%5B1\%5D.pdf (accessed on 24 October 2018).

76. Glaze, A.L.; Goldston, M.J. U.S. Science Teaching and Learning of Evolution: A Critical Review of the Literature 2000-2014. Sci. Educ. 2015, 99, 500-518. [CrossRef]

77. Van der Zanden, P.J.; Denessen, E.; Cillessen, A.H.; Meijer, P.C. Domains and predictors of first-year student success: A systematic review. Educ. Res. Rev. 2018, 23, 57-77. [CrossRef]

78. Heath, P.A.; Hawk, R. Deciding about energy. Sci. Child. 1983, 20, 86-88.

79. Rönnebeck, S.; Bernholt, S.; Ropohl, M. Searching for a common ground-A literature review of empirical research on scientific inquiry activities. Stud. Sci. Educ. 2016, 52, 161-197. [CrossRef]

80. *Gresch, H.; Bögeholz, S. Identifying Non-Sustainable Courses of Action: A Prerequisite for Decision-Making in Education for Sustainable Development. Res. Sci. Educ. 2013, 43, 733-754. [CrossRef]

81. * Gresch, H.; Hasselhorn, M.; Bögeholz, S. Training in Decision-making Strategies: An approach to enhance students' competence to deal with socio-scientific issues. Int. J. Sci. Educ. 2013, 35, 2587-2607. [CrossRef]

82. * Belova, N.; Eilks, I.; Feierabend, T. The evaluation of role-playing in the context of teaching climate change. Int. J. Sci. Math. Educ. 2015, 13, 165-190. [CrossRef] 
83. * Eggert, S.; Nitsch, A.; Boone, W.J.; Nückles, M.; Bögeholz, S. Supporting Students' Learning and Socioscientific Reasoning About Climate Change-The Effect of Computer-Based Concept Mapping Scaffolds. Res. Sci. Educ. 2017, 47, 137-159. [CrossRef]

84. * Gresch, H.; Hasselhorn, M.; Bögeholz, S. Enhancing Decision-Making in STSE Education by Inducing Reflection and Self-Regulated Learning. Res. Sci. Educ. 2017, 47, 95-118. [CrossRef]

85. * Mannion, G. Borderland voices and practices: The ambiguity of children's participation in school ground greening. Can. J. Environ. Educ. 2005, 10, 241-255.

86. * Grace, M. Developing High Quality Decision-Making Discussions About Biological Conservation in a Normal Classroom Setting. Int. J. Sci. Educ. 2009, 31, 551-570. [CrossRef]

87. * Nicolaou, C.T.; Korfiatis, K.; Evagorou, M.; Constantinou, C. Development of decision-making skills and environmental concern through computer-based, scaffolded learning activities. Environ. Educ. Res. 2009, 15, 39-54. [CrossRef]

88. * Paraskeva-Hadjichambi, D.; Hadjichambis, A.C.; Korfiatis, K. How students' values are intertwined with decisions in a socio-scientific issue. Int. J. Environ. Sci. Educ. 2015, 10, 493-513.

89. * Dori, Y.J.; Tal, R.T. Formal and informal collaboration projects: Engaging in industry with environmental awareness. Sci. Educ. 2000, 84, 95-113. [CrossRef]

90. * Jager, H.d.; van der Loo, F. Decisionmaking in Environmental Education: Notes from Research in the Dutch NME-VO Project. J. Environ. Educ. 1990, 22, 33-42. [CrossRef]

91. * Cincera, J.; Kovacikova, S. Being an EcoTeam Member: Movers and Fighters. Appl. Environ. Educ. Commun. 2014, 13, 227-233. [CrossRef]

92. * Jime'nez-Aleixandre, M.-P. Knowledge producers or knowledge consumers? Argumentation and decision making about environmental management. Int. J. Sci. Educ. 2002, 24, 1171-1190. [CrossRef]

93. * Siegel, M.A. High school students' decision making about sustainability. Environ. Educ. Res. 2006, 12, 201-215. [CrossRef]

94. * Levine Rose, S.; Calabrese Barton, A. Should great lakes city build a new power plant? How youth navigate socioscientific issues. J. Res. Sci. Teach. 2012, 49, 541-567. [CrossRef]

95. * Emery, K.; Harlow, D.; Whitmer, A.; Gaines, S. Compelling evidence: An influence on middle school students' accounts that may impact decision-making about socioscientific issues. Environ. Educ. Res. 2017, 23, 1115-1129. [CrossRef]

96. * Roth, W.-M.; Lee, S. Science education as/for participation in the community. Sci. Educ. 2004, 88, $263-291$. [CrossRef]

97. * Kim, M.; Tan, H.T. A Collaborative Problem-solving Process through Environmental Field Studies. Int. J. Sci. Educ. 2013, 35, 357-387. [CrossRef]

98. Eggert, S.; Bögeholz, S. Students' use of decision-making strategies with regard to socioscientific issues: An application of the Rasch partial credit model. Sci. Educ. 2010, 94, 230-258. [CrossRef]

99. Schneider, J.; Hutt, E. Making the grade: A history of the A-F marking scheme. J. Curric. Stud. 2014, 46, 201-224. [CrossRef]

100. Köller, O.; Trautwein, U.; Lüdtke, O.; Baumert, J. Zum Zusammenspiel von schulischer Leistung, Selbstkonzept und Interesse in der gymnasialen Oberstufe [The interaction of acadamic achievment, self-concept and interest in high school]. Z. Padagog. Psychol. 2006, 20, 27-39. [CrossRef]

101. Steffen, B.; Hößle, C. "Dafür bin ich nicht ausgebildet, dafür bin ich nicht fortgebildet." Diagnose von Bewertungskompetenz durch Biologielehrkräfte als "Negiertes Bewältigen" ["I cannot do this, I am not educated in this" biology teachers' diagnosis of decision-making as "negated coping"]. In Befähigung zu gesellschaftlicher Teilhabe [Empowerment to Civic Participation]; Menthe, J., Höttecke, D., Zabka, T., Hammann, M., Rothgangel, M., Eds.; Waxmann: Münster, Gernamy; New York, NY, USA, 2016; pp. 95-106.

102. Aikenhead, G.S. Collective decision making in the social context of science. Sci. Educ. 1985, 69, $453-475$. [CrossRef]

103. Reischert, K.; Hößle, C. Wie Schüler ethisch bewerten. Eine qualitative Untersuchung zur Strukturierung und Ausdifferenzierung von Bewertungskompetenz in bioethischen Sachverhalten bei Schülern der Sek. I.: [How students judge ethically. A qualitative study on the structure and differentiation of competence of moral judgement with respect to bioethical issues concerning students of Sek. I]. Zeitschrift für Didaktik der Naturwissenschaften 2007, 13, 125-143. 
104. Zeidler, D.L.; Sadler, T.D. Social and Ethical Issues in Science Education: A Prelude to Action. Sci. Educ. 2008, 17, 799-803. [CrossRef]

105. Grace, M.M.; Ratcliffe, M. The science and values that young people draw upon to make decisions about biological conservation issues. Int. J. Sci. Educ. 2002, 24, 1157-1169. [CrossRef]

106. Acar, O.; Turkmen, L.; Roychoudhury, A. Student Difficulties in Socio-scientific Argumentation and Decision-making Research Findings: Crossing the borders of two research lines. Int. J. Sci. Educ. 2009, 32, 1191-1206. [CrossRef]

107. Elliott, J.A. Introduction to Sustainable Development; Routledge: London, UK, 2012.

108. Evans, R.T.; Kilinc, E. History of place-based education in the school studies field. Adiyaman Univ. J. Soc. Sci. 2013, 11, 2233-2237.

109. Dewey, J. The School and Society, 2nd ed.; University of Chicago Press: Chicago, IL, USA, 1915.

110. Brkich, K.L. Urban fifth graders' connections-making between formal earth science content and their lived experiences. Cult. Stud. Sci. Educ. 2014, 9, 141-164. [CrossRef]

111. Gruenewald, D.A.; Koppelman, N.; Elam, A. Our place in history: Inspiring place-based social history in schools and communities. J. Mus. Educ. 2007, 32, 231-240. [CrossRef]

112. Gruenewald, D.A.; Smith, G.A. Making room for the local. In Place-Based Education in the Global Age: Local Diversity; Gruenewald, D.A., Smith, G.A., Eds.; Lawrence Erlbaum Associates: New York, NY, USA, 2007; pp. xiii-xxiii.

113. Holfelder, A.-K. Orientierungen von Jugendlichen zu Nachhaltigkeitsthemen: zur Didaktischen Bedeutung von Implizitem Wissen im Kontext BNE [Young Peoples' Orientation in Topics Related to Sustainable Development. The Educational Meaning of Implicit Knowledge in the Context of EDS]; Springer Fachmedien Wiesbaden: Wiesbaden, Germany, 2018.

114. Akin, S.; Calik, B.; Engin-Demir, C. Students as Change Agents in the Community: Developing Active Citizenship at Schools. Educ. Sci. Theor. Pract. 2017, 17, 809-834. [CrossRef]

115. Chawla, L.; Cushing, D.F. Education for strategic environmental behavior. Environ. Educ. Res. 2007, 13, 437-452. [CrossRef]

116. Wals, A.E. Mirroring, Gestaltswitching and transformative social learning. Int. J. Sustain. High. Ed. 2010, 11, 380-390. [CrossRef]

117. Tilbury, D.; Wortman, D. Engaging People in Sustainability; IUNC: Grand, UK, 2004.

118. Robson, C. Real World Research, 3rd ed.; Wiley: Chichester, UK, 2011.

119. James, A.; Prout, A. Constructing and Reconstructing Childhood; Falmer: Basingstoke, UK, 1990.

120. Bae, S.H. Values and Prospects of Extended Education: A Critical Review of the Third NEO ER Meeting. Int. J. Res. Ext. Educ. 2014, 2, 135-141. [CrossRef]

121. Pocock, S.J.; Collier, T.J.; Dandreo, K.J.; de Stavola, B.L.; Goldman, M.B.; Kalish, L.A.; Kasten, L.E.; McCormack, V.A. Issues in the reporting of epidemiological studies: A survey of recent practice. BMJ 2004, 329, 883-888. [CrossRef] [PubMed]

122. Seow, P.-S.; Pan, G. A Literature Review of the Impact of Extracurricular Activities Participation on Students' Academic Performance. J. Educ. Bus. 2014, 89, 361-366. [CrossRef]

123. Zeidler, D.L. Socioscientific issues as a curriculum emphasis. In Handbook of Research on Science Education Volume II; Lederman, N.G., Abell, S.K., Eds.; Routledge: London, UK, 2014; pp. 697-726.

124. Owens, D.C.; Sadler, T.D.; Zeidler, D.L. Controversial issues in the science classroom. Phi Delta Kappan 2017, 99, 45-49. [CrossRef]

125. Reitschert, K.; Hößle, C. Ethisches Bewerten im Biologieunterricht [Ethical decision-making in the biology classroom]. In Fachmethodik: Biologie-Methodik: Handbuch für die Sekundarstufe I und II: [Methods for biology education: A guideline for Sek I and Sek II]; Spörhase, U., Ruppert, W., Eds.; Cornelson: Berlin, Germany, 2010; pp. 227-230.

126. Ratcliffe, M. Pupil decision-making about socio-scientific issues within the science curriculum. Int. J. Sci. Educ. 1997, 19, 167-182. [CrossRef]

127. Bourn, D. Teachers as agents of social change. Int. J. Dev. Educ. Glob. Learn. 2016, 7, 63-77. [CrossRef] 
128. Mezirow, J. Transformative Learning: Theory to Practice. New Dir. Adult Contin. Educ. 1997, 1997, 5-12. [CrossRef]

129. Wals, A.E.; Jickling, B. "Sustainability" in higher education. Int. J. Sustain. High. Ed. 2002, 3, $221-232$. [CrossRef] 